\title{
Bromatological analysis of millet cv. Ceará (Pennisetum glaucum) irrigated with treated gray water dilutions in well water
}

\begin{abstract}
The present work aimed to analyze the viability of gray water use on bromatological quality of millet cv. Ceará (Pennisetum glaucum). The experiment was carried out in the greenhouse, on the department of agronomic and forestry sciences at the Federal Rural University of the Semi-Arid - UFERSA, Mossoró, RN, Brazil. The experimental design used was randomized blocks with five treatments and six replications, totaling thirty plots. The experiment was carried out in vases with the volume of $25 \mathrm{~L}$ containing four plants per vase. The treatments consisted in five dilutions of TGW in WW: T1 $100 \% \mathrm{WW}$ plus $0 \% \mathrm{TGW}$; $2-75 \% \mathrm{WW}$ plus $25 \% \mathrm{TGW}$; $\mathrm{T} 3-50 \% \mathrm{WW}$ plus $50 \%$ TGW; T4 - 25\% WW plus $75 \% \mathrm{TGW}$ and $\mathrm{T} 5-0 \% \mathrm{WW}$ plus $100 \%$ TGW. It was analyzed dry matter, ashes, fibers in neutral and acid detergents, nitrogen and protein indigestible in acid detergent and crude protein. From the presented results, it can be concluded that the dilution that promoted better bromatological quality was treatment T3 with $50 \%$ of treated gray water plus $50 \%$ of well water, however, forage production irrigated only with treated gray water shown to be used in semiarid regions.
\end{abstract}

Keywords: Pennisetum glaucum, sustainability, forage
Volume 2 Issue 5 - 2018

Allana Rayra Holanda Sotero, Mychelle Karla
Teixeira de Oliveira, Rafael Oliveira Batista,
Francisco de Assis de Oliveira, Ricardo
André Rodrigues Filho, Audilene Dantas da
Silva
Department of Agronomic and Forestry Sciences, Federal Rural

University of the Semi-Arid, Brazil

Correspondence: Mychelle Karla Teixeira de Oliveira, Department of Agronomic and Forestry Sciences, Federal Rural University of the Semi-Arid,Av. Francisco Mota, 572 - Bairro Costa e Silva, Mossoró, RN, Tel +55 84 99118-825I, Email mymykar@gmail.com

Received: October 24, 2018 | Published: October 29, 2018

\section{Introduction}

Only a small perceptual of all planet's water presents as fresh and available to population's use. Water of quality is becoming scarcer with environmental pollution and its use is getting restricted to supply human needs. ${ }^{1}$ The semiarid region is characterized for having variations in rainfall with long periods of drought and only few months with rain throughout the year, high evapotranspiration rate and poor and shallow soils. ${ }^{2}$ Many animals raised by small farmers are fed in extensive regime, which the animals must search their own food, or semi-intensive, which they spend part of their time in pasture and the other part of the food is provided by the farmer. However, vegetation of semiarid regions presents low capacity to supply animals demand during dry season, besides it is difficult to produce a pasture of quality with water scarcity and with poor soils. ${ }^{3}$

The Millet (Pennisetum glaucum) is a good alternative for animals feeding in these regions, it is a rustic culture with low demand for inputs when compared to other forages, it produces silage of good nutritional quality, establishes easily and is has good palatability. The use of wastewater on irrigation shows to be promising. ${ }^{4}$ Some research has shown that, Brachiaria brizantha cv. Mandaru presented rise in dry matter and crude protein contents and reduction in fiber in neutral and acid nutrients, and also obtained higher content of crude protein in Tifton and black oat irrigated with cattle wastewater than with mineral fertilization. ${ }^{5,6}$ The gray water is a domestic wastewater from sinks, showers, washing machines, etc. except from toilets. Its use projection on irrigation can be viable since it presents low fecal contamination than other wastewaters and it is produced in great amount on residences. Thus, this work aimed to analyze viability of gray water's use to analyse its effect on bromatological quality of millet forage.

\section{Methods}

The experiment was carried out on greenhouse, on the department of agronomic and forestry sciences at the Federal Rural University of the Semi-Arid - UFERSA, Mossoró, RN, Brazil (05¹2'03.9” S; 37¹9'98" W). according to koppen's climate classification, the region's climate is classified as BSh, which is a country climate, semiarid, warm and dry, with low altitude and latitude, morphoclimatic domain caatinga, average annual rainfall lower than $650 \mathrm{~mm}$ and average annual temperature higher than $265^{\circ} \mathrm{C} .^{7}$ In this region the average annual rainfall is $673.9 \mathrm{~mm}$, humidity of $65.9 \%$ and average speed of wind is $3.32 \mathrm{~ms}^{-1}{ }^{8.9}$ The experimental design used was randomizes blocks with five treatments and six replications, totaling thirty plots. The experiment was carried out in vases with volume of $25 \mathrm{~L}$ containing four plants per vase. The treatments consisted in five dilutions of TGW in WW: T1 $-100 \% \mathrm{WW}$ plus $0 \% \mathrm{TGW}$; 2 $-75 \%$ WW plus $25 \%$ TGW; T3 - 50\% WW plus 50\% TGW; T4 $25 \% \mathrm{WW}$ plus $75 \% \mathrm{TGW}$ and T5 $-0 \% \mathrm{WW}$ plus $100 \%$ TGW. Gray water dilutions are recommended to reduce salt concentration and to identify the most adequate dilution to culture development. ${ }^{8,10} \mathrm{As}$ substrate, it was used soil classified as Typic Rhodustults, collected from the experimental farm Rafael Fernandes, Mossoro, RN, whose chemical characteristics are presented on Table 1. ${ }^{11}$

The gray water was collected from a treatment station located on Monte Alegre I settlement (5 $5^{\circ}$ "13.06" S; 37 $27^{\prime} 23.27^{\prime}$ W) in Upanema, RN. The gray water produced in the residence is composed by shower, bathroom sink and laundry tanks. The house is inhabited by two people and they have three visitors on weekends, producing average of $80 \mathrm{~L}$ of gray water per day. The applications of gray water dilutions in well water was carried out through an irrigation system of microtubes with a PVC reservoir (60L), an circulating pump Metalcorte/Eberle, self-ventilated, EBD250076 model, lateral lines of $16 \mathrm{~mm}$ and microtubes with average flow of $8.5 \mathrm{~L} \mathrm{~h}^{-1}$. The irrigation system applied, daily, the needed volume of dilutions to increase soil humidity until its maximum water retention capacity. The climatic data were collected inside the greenhouse during the experimental period, minimum (MinTem), medium (MedTem) and maximum (MaxTem) 
temperatures, minimum (MinRH), medium (MedRH) and maximum humidity, the variations were from 38.9 to $57.8 \%$ for MinRH, 41.8 to $(\mathrm{MaxRH})$ relative humidity and global radiation. Temperatures varied $\quad 60.3 \%$ for MedRH and 44.7 to $62.9 \%$ for MaxRH (Figure 1B). Solar from 26.8 to $29.1^{\circ} \mathrm{C} ; 27.6$ to $29.8^{\circ} \mathrm{C} ; 28.3$ to $30.6^{\circ} \mathrm{C}$, to minimum, radiation inside the greenhouse varied from 14.9 to $26.7 \mathrm{MJ} \mathrm{m}^{-2}$ with medium and maximum, respectively (Figure 1A). For relative average of $20.2 \mathrm{MJ} \mathrm{m}^{-2}$ (Figure 1C) (Table 2).

Table I Chemical characteristic of soil before irrigation with treated gray water dilutions in well water

\begin{tabular}{|c|c|c|c|c|c|c|c|c|c|c|c|c|c|c|c|}
\hline Depth & pH & EC & OM & $\mathbf{P}$ & $\mathbf{K}^{+}$ & $\mathrm{Na}^{+}$ & $\mathrm{Ca}^{2+}$ & $\mathrm{Mg}^{2+}$ & $\mathbf{A l}^{3+}$ & $\mathrm{H}+\mathrm{Al}$ & SB & $\mathbf{T}$ & CEC & $\mathbf{v}$ & ESP \\
\hline$(\mathrm{cm})$ & (water) & $d \mathrm{Sm}^{-1}$ & \multicolumn{4}{|c|}{--------mg dm-3 -------- } & \multicolumn{7}{|c|}{ - } & \multicolumn{2}{|c|}{$---\%$--- } \\
\hline $0-20$ & 6.10 & 0.41 & 3.31 & 1.90 & 26.90 & 4.70 & 1.10 & 0.70 & 0.00 & 1.49 & 1.89 & 1.89 & 3.37 & 56 & I \\
\hline $20-40$ & 4.80 & 0.03 & 2.07 & 1.70 & 26.90 & 4.70 & 0.40 & 1.00 & 0.15 & 1.98 & 1.49 & 1.64 & 3.47 & 43 & I \\
\hline
\end{tabular}

Note: $\mathrm{pH}$, Hydrogen potential; $\mathrm{EC}$, electrical conductivity; OM, organic matter; $\mathrm{P}$, phosphorus; $\mathrm{K}$, potassium; $\mathrm{Na}^{+}$, sodium; $\mathrm{Ca}^{2+}$, calcium; $\mathrm{Mg}^{2+}$, Magnesium; $\mathrm{Al}^{3+}$, Aluminium; $(\mathrm{H}+\mathrm{AL})$, potential acidity; SB, Sum of bases; $\mathrm{CEC}$, cátion; ESP, Exchange capacity; $\mathrm{V}$, Base saturation; ESP, exchangeable sodium percentage.

Table 2 Physico-chemical characteristics of treated gray water (TGW) and well water (WW) and its related average (A) and standard deviation (SD)

\begin{tabular}{|c|c|c|c|c|c|c|c|c|}
\hline & \multicolumn{2}{|c|}{$08 / 21 / 2017$} & \multicolumn{2}{|c|}{$09 / 21 / 2017$} & \multicolumn{2}{|c|}{$10 / 16 / 2017$} & \multirow{2}{*}{ 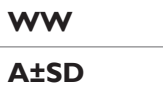 } & \multirow{2}{*}{$\begin{array}{l}\text { TGW } \\
\mathrm{A} \pm S D\end{array}$} \\
\hline & WW & TGW & WW & TGW & WW & TGW & & \\
\hline $\mathrm{Al}\left(\mathrm{mg} \mathrm{L}^{-1}\right)$ & 0.213 & 0.125 & 0.084 & 0.099 & 0.053 & 0.133 & $0.117 \pm 0.085$ & $0.119 \pm 0.018$ \\
\hline As $\left(m g L^{-1}\right)$ & 0 & 0 & 0.000 & 0.000 & 0.000 & 0.000 & $0 \pm 0$ & $0.000 \pm 0.000$ \\
\hline $\mathrm{B}\left(\mathrm{mg} \mathrm{L}^{-1}\right)$ & 0.512 & 0.366 & 0.415 & 0.244 & 0.350 & 0.412 & $0.426 \pm 0.082$ & $0.34 I \pm 0.087$ \\
\hline $\mathrm{Ba}\left(\mathrm{mg} \mathrm{L}^{-1}\right)$ & $1.84 \mid$ & 1.948 & 2.632 & 2.281 & 2.323 & 1.868 & $2.265 \pm 0.399$ & $2.032 \pm 0.219$ \\
\hline $\mathrm{Cr}\left(\mathrm{mg} \mathrm{L}^{-1}\right)$ & 0.064 & 0.105 & 0.012 & 0.000 & 0.013 & 0.004 & $0.030 \pm 0.030$ & $0.036 \pm 0.060$ \\
\hline $\mathrm{Cu}\left(\mathrm{mg} \mathrm{L}^{-1}\right)$ & 0.006 & 0.039 & 0.088 & 0.08 & 0.088 & 0.088 & $0.06 I \pm 0.047$ & $0.069 \pm 0.026$ \\
\hline$M n\left(m g L^{-1}\right)$ & 0.029 & 0.377 & 0.062 & 0.177 & 0.061 & 0.124 & $0.051 \pm 0.019$ & $0.226 \pm 0.133$ \\
\hline $\mathrm{Fe}\left(\mathrm{mg} \mathrm{L}^{-1}\right)$ & 0.03 & 1.404 & 0.087 & 0.498 & 0.094 & 0.471 & $0.070 \pm 0.035$ & $0.79| \pm 0.53|$ \\
\hline $\mathrm{Ni}\left(\mathrm{mg} \mathrm{L}^{-1}\right)$ & 0.081 & 0.053 & 0.012 & 0.000 & 0.015 & 0.028 & $0.036 \pm 0.039$ & $0.027 \pm 0.027$ \\
\hline $\mathrm{Cd}\left(\mathrm{mg} \mathrm{L}^{-1}\right)$ & 0 & 0 & 0.018 & 0.006 & 0.020 & 0.025 & $0.013 \pm 0.011$ & $0.010 \pm 0.013$ \\
\hline $\mathrm{Pb}\left(\mathrm{mg} \mathrm{L}^{-1}\right)$ & 0.06 & 0.049 & 0.002 & 0.043 & 0.001 & 0.04 & $0.021 \pm 0.034$ & $0.044 \pm 0.005$ \\
\hline $\mathrm{Zn}\left(\mathrm{mg} \mathrm{L^{-1 }}\right)$ & 0.018 & 0.291 & 0.031 & 0.076 & 0.034 & 0.076 & $0.028 \pm 0.009$ & $0.148 \pm 0.124$ \\
\hline $\mathrm{pH}$ & 7.1 & 7.5 & 7.12 & 7.59 & 7.05 & 7.97 & $7.090 \pm 0.030$ & $7.693 \pm 0.242$ \\
\hline $\mathrm{EC}\left(\mathrm{dS} \mathrm{m}^{-1}\right)$ & 0.5 & 1.4 & 0.42 & 1.33 & 0.52 & $\mathrm{I} .70$ & $0.467 \pm 0.050$ & $1.477 \pm 0.197$ \\
\hline $\mathrm{K}^{+}\left(\mathrm{mmol}_{\mathrm{c}} \mathrm{L}^{-1}\right)$ & 0.2 & 1.3 & 0.21 & 1.08 & 0.20 & 1.34 & $0.209 \pm 0.008$ & I. $246 \pm 0.144$ \\
\hline $\mathrm{Na}^{+}\left(\mathrm{mmol}_{\mathrm{c}} \mathrm{L}^{-1}\right)$ & 5.4 & 8.2 & 3.75 & 6.22 & 3.50 & 10.89 & $4.202 \pm 1.008$ & $8.431 \pm 2.345$ \\
\hline $\mathrm{Ca}^{2+}\left(\mathrm{mmol}_{\mathrm{c}} \mathrm{L}^{-1}\right)$ & 0.5 & 3.3 & 0.55 & 4.8 & 0.67 & 1.84 & $0.586 \pm 0.073$ & $3.280 \pm 1.455$ \\
\hline $\mathrm{Mg}^{2+}\left(\mathrm{mmol}_{\mathrm{c}} \mathrm{L}^{-1}\right)$ & 0.3 & 2.1 & 0.20 & 0.86 & 0.43 & 4.98 & $0.322 \pm 0.116$ & $2.638 \pm 2.117$ \\
\hline $\mathrm{Cl}^{-}\left(\mathrm{mmol}_{\mathrm{c}} \mathrm{L}^{-1}\right)$ & 2.9 & 8.5 & 1.20 & 5.40 & 2.00 & 6.40 & $2.022 \pm 0.834$ & $6.778 \pm 1.600$ \\
\hline $\mathrm{CO}_{3}^{2-}\left(\mathrm{mmol}_{\mathrm{c}} \mathrm{L}^{-1}\right)$ & 0.0 & 0.0 & 0.20 & 0.40 & 0.20 & 0.50 & $0.133 \pm 0.115$ & $0.300 \pm 0.265$ \\
\hline $\mathrm{HCO}_{3}^{-}\left(\mathrm{mmol}_{\mathrm{c}} \mathrm{L}^{-1}\right)$ & 2.6 & 7.8 & 1.30 & 2.60 & 2.50 & 7.50 & $2.144 \pm 0.734$ & $5.967 \pm 2.919$ \\
\hline$N\left(m g L^{-1}\right)$ & - & - & - & 40.43 & - & 34.56 & - & $37.49 \pm 2.940$ \\
\hline$P\left(m g L^{-1}\right)$ & - & - & - & 4.74 & - & 2.54 & - & $3.640 \pm 1.100$ \\
\hline
\end{tabular}

Table 3 Volume in liters of treated gray water (TGW) dilutions in well water (WW) and applied during the experimental period

\begin{tabular}{|c|c|c|c|c|c|c|c|c|c|}
\hline \multirow{2}{*}{ Treatments } & \multicolumn{2}{|c|}{ I-20 DAS } & \multicolumn{2}{|c|}{$21-40$ DAS } & \multicolumn{2}{|c|}{ 4I-65 DAS } & \multicolumn{2}{|c|}{ Accumulated } & \multirow{2}{*}{ Total } \\
\hline & WW & TGW & WW & TGW & WW & TGW & WW & TGW & \\
\hline & \multicolumn{9}{|c|}{ Liters per vase } \\
\hline TI & 71.30 & 0.00 & 30.80 & 0.00 & 57.30 & 0.00 & 159.40 & 0.00 & 159.40 \\
\hline $\mathrm{T} 2$ & 71.30 & 0.00 & 23.10 & 7.70 & 43.00 & 14.30 & 137.40 & 22.00 & 159.40 \\
\hline T3 & 71.30 & 0.00 & 15.40 & 15.40 & 28.65 & 28.65 & 115.45 & 44.05 & 159.40 \\
\hline $\mathrm{T} 4$ & 71.30 & 0.00 & 7.70 & 23.10 & 14.30 & 43.00 & 93.30 & 66.10 & 159.40 \\
\hline T5 & 71.30 & 0.00 & 0.00 & 30.80 & 0.00 & 57.30 & 71.30 & 88.10 & 159.40 \\
\hline
\end{tabular}

Note: DAS, Days after sowing;TI, I00\%WW plus 0\% TGW;T2, 75\%WW plus 25\% TGW;T3, 50\% WW plus 50\% TGW;T4, 25\% WW plus 75\% TGW and T5, $0 \%$ WW plus $100 \%$ TGW. 


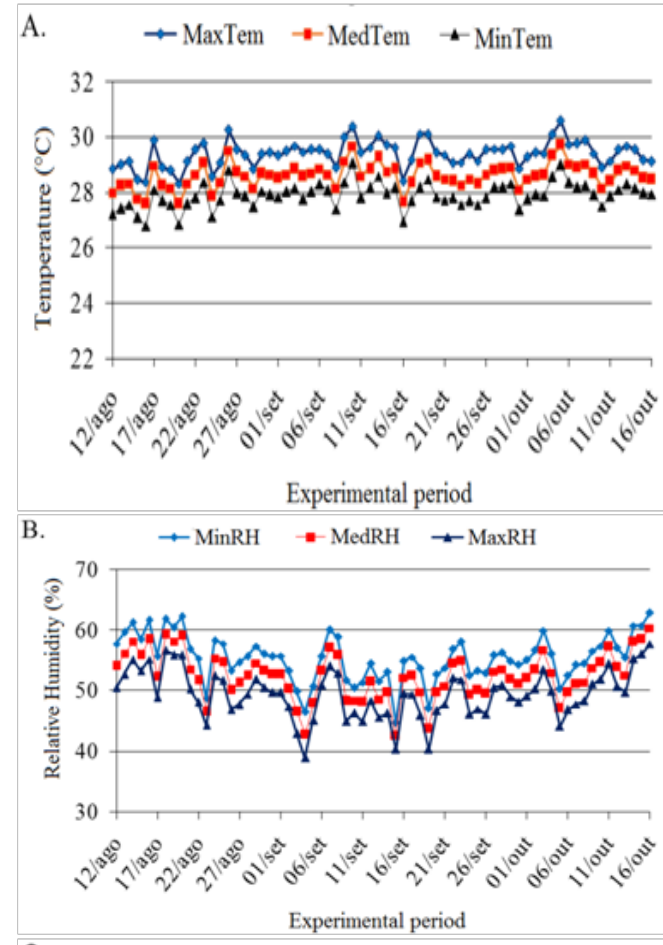

C.

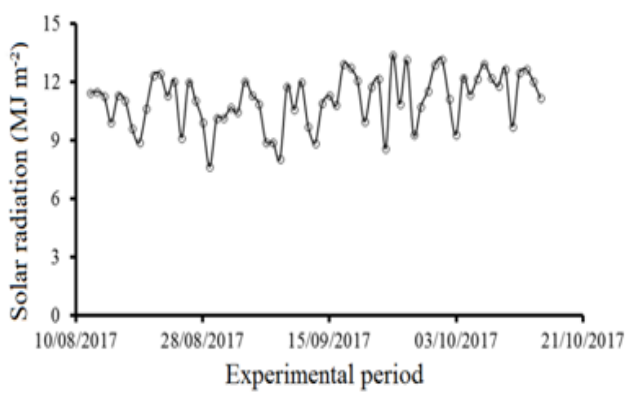

Figure I Climate data (A) Temperature; (B) Air relative humidity; (C) Solar radiation; obtained during the experimental period.

On Table 3 it is presented the volume of water applied during the experiment, showing that it was applied a total volume of $159.4 \mathrm{~L}$ per vase in the end of the experiment for all treatments. Considering that treatments $\mathrm{T} 4$ and $\mathrm{T} 5$ received higher volumes of treated gray water, there was economy of 75 and $100 \%$ of well water for forage production, higher than forage production of treatment $\mathrm{T} 1$, that only used well water. The materials were collected manually on October $16^{\text {th }}$ of 2017,65 days after sowing. Plants were cutted $0.05 \mathrm{~m}$ above the soil taking all its leaves and putted in paper bags. The material was weighted fresh to determine fresh matter and later sent to hothouse with forced air circulation on $65^{\circ} \mathrm{C}$ until it gets to constant weight to obtain dry matter. Then, the material was milled in Willey Mill and kept in plastic bags to go to laboratory analysis. On bromatology lab, the material went through analyses of neutral and acid detergent fiber (NDF and ADF), nitrogen and protein indigestible in acid detergent (NIDA and PIDA), and dry matter content, ashes and crude protein., ${ }^{3,12}$ The millet data of development and production were submitted to analysis of variance, using test $\mathrm{F}$ with $5 \%$ of probability. The means were compared though tukey test with $5 \%$ of probability. Regression models were chosen based on determination coefficient values and regression equation coefficients, using test $\mathrm{F}$ with $5 \%$ of probability. Statistical analysis of data was carried out with aid of SISVAR programa. ${ }^{13}$

\section{Results}

The analyzes show that with exception of neutral and acid detergent fibers, the other variables were influenced by the treatments with significant differences of $5 \%$ and $1 \%$ (Table 4 ). The contents of dry matter and ashes presented reductions of $12.1 \%$ and $37.1 \%$, respectively, when increased gray water concentration on dilutions (Figure 2A) \& (Figure 2B). The content of NIDA and crude protein presented parabolic behavior, with initial reduction of its contents with increase in gray water's concentration in dilutions, and later increase. Its highest contents were obtained on treatments $\mathrm{T} 1,48 \%$ superior to the lower content, and T5, 56\% superior to the lower content (Figure 2C), (Figure 2D), (Figure 2E), (Figure 2F) \& (Figure 2G). The content of PIDA presented rose with increase in gray water dose, being $263 \%$ superior to treatments T1, only with well water (Figure 2F).
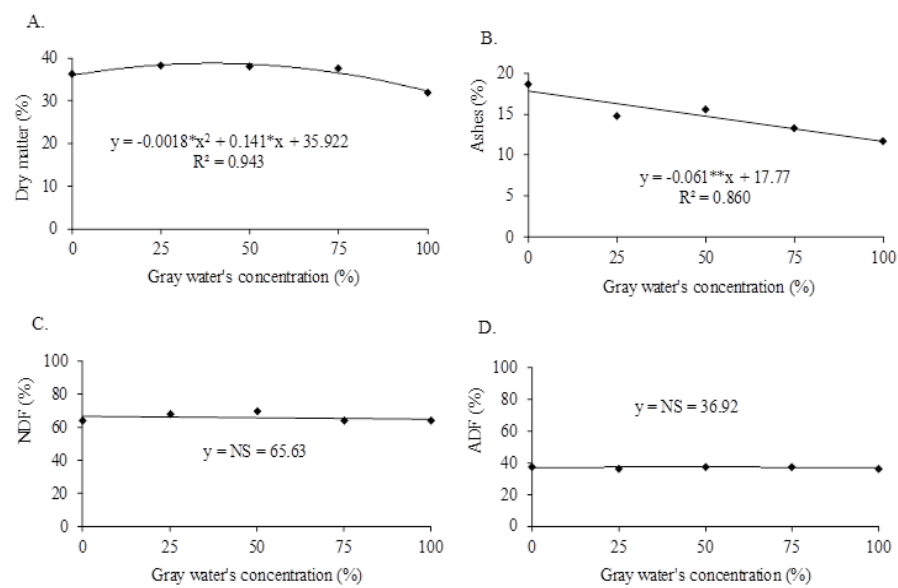

D.
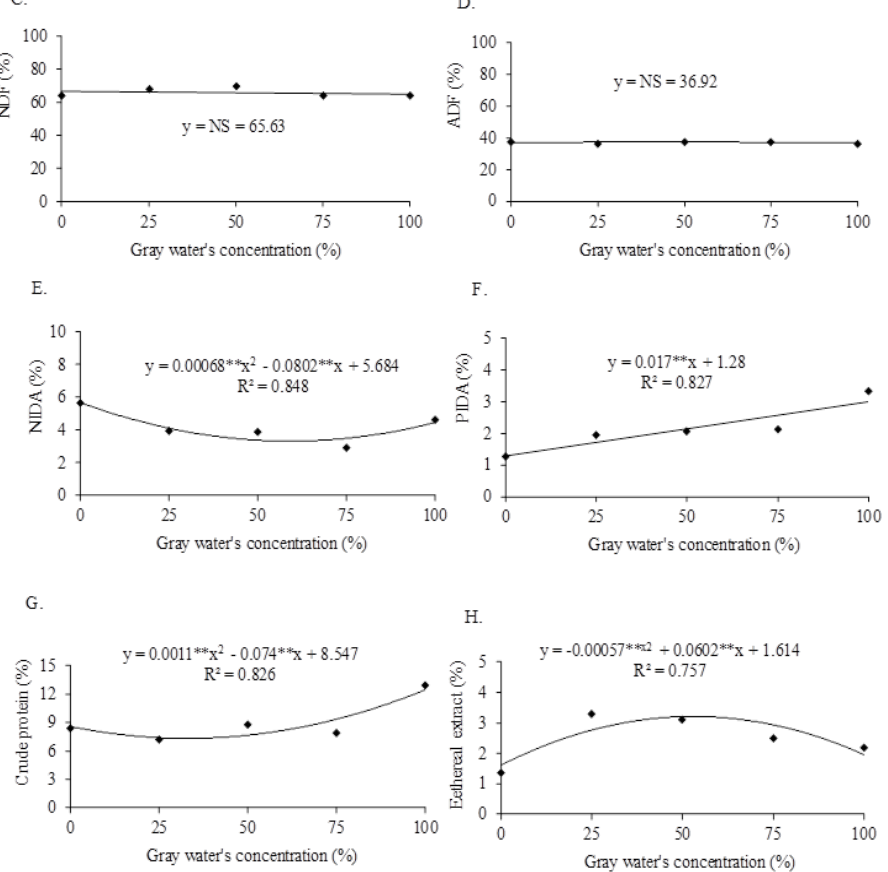

Figure 2 Dry matter (A) Ashes; (B) Neutral detergent fiber; (C) Acid detergent fiber; (D) Nitrogen indigestible in acid detergent; (E) Protein indigestible in acid detergent; $(F)$ and crude protein; $(G)$ of millet produced with treated gray water dilutions in well water. 
Table 4 Summary of variance analysis of dry matter (DM), ashes (A), neutral detergent fiber (NDF), acid detergent fiber (ADF), nitrogen indigestible in acid detergent (NIDA), protein indigestible in acid detergent (PIDA) and crude protein (CP) of millet produced with treated gray water dilutions in well water

\begin{tabular}{lllllllll}
\hline \multirow{2}{*}{ Variation sources } & DF & \multicolumn{2}{l}{ Mean square } & & & & \\
\cline { 3 - 9 } & & DM & A & NDF & ADF & NIDA & PIDA & CP \\
\hline Gray water & 4 & $41.80^{*}$ & $47.73^{* *}$ & $43.07^{\text {ns }}$ & $2.01^{\text {ns }}$ & $6.12^{* *}$ & $3.37^{*}$ & $30.00^{* *}$ \\
Blocks & 5 & $46.08^{*}$ & $1.26^{\text {ns }}$ & $7.25^{\text {ns }}$ & $1.29^{\text {ns }}$ & $0.83^{\text {ns }}$ & $0.27^{\text {ns }}$ & $4.79^{\text {ns }}$ \\
Error & 20 & 13.51 & 4.27 & 20.98 & 5.03 & 0.90 & 0.82 & 2.57 \\
\hline CV $(\%)$ & & 10.13 & 13.59 & 6.98 & 6.08 & 22.50 & 42.31 & 17.67 \\
\hline
\end{tabular}

Note: *, ** significant to $5 \%$ and I\% of probability, respectively, by $\mathrm{F}$ test. Ns non-significant by $\mathrm{F}$ test.

\section{Discussion}

The increase in treated gray water dose promoted rise in millet's crude protein, with structural importance on animals, as well as for its maintenance, growth and production., however, when in excess, protein is lost as urea. There was also an increase in PIDA and NIDA contents, which is the fiber not available for the animal, and reduction on dry matter and ashes. Similarly, the authors obtained higher crude protein content and reduction on neutral detergent fiber (FDN), with no significant difference on FDA and dry matter contents on Tifton 85 submitted to different doses of nitrogen. And other found different results with increase in dry matter of sorghum irrigated with domestic wastewater. ${ }^{10,14}$ Using wastewater from different origins, the author found reduction on dry matter content and rise in crude protein and neutral and acid detergent fibers on Brachiaria brizantha and other found increase on crude protein with no significant difference on dry matter content compared to mineral fertilization. ${ }^{5,6}$

\section{Conclusion}

It can be said that gray water implementation was benefic to bromatological quality of the forage, since the best result can be found on dilutions. The dilution of $50 \%$ of treated gray water plus $50 \%$ of well water presented medium contents of crude protein, important to gain of weight, dry matter, ashes, NIDA and PIDA. It can be concluded that gray water is viable to millet's forage production in semiarid regions.

\section{Funding details \\ UFERSA, CAPES, CNPq}

\section{Acknowledgements}

The present work was carried out with the support of CNPq, National Council of Scientific and Technological Development, Brazil (150293/2017-8), and Federal Rural University of the Semi-Arid (UFERSA). The first author credits the research grant awarded by the Coordination for the Improvement of Higher Education Personnel (CAPES).

\section{Conflict of interest}

Authors declare that there is no conflict of interest.

\section{References}

1. Augusto LGS, Gurgel IGD, Câmara Neto HF, et al. The global and national context of the challenges of adequate access to water for human consumption. Ciência \& saúde coletiva. 2012;17(6):1511-1522.
2. Barbosa JEL, Medeiros ESF, Brasil J, et al. Aquatic systems in semi-arid Brazil: limnology and management. Acta Limnologica Brasiliensia. 2012;24(1):103-118.

3. Correia RC, Kiill LHP, Moura MSB, et al. The semi-arid region of Brazil. In: Voltolini TV, Editor. Production of goats and sheep in the Semi-arid. Petrolina: Embrapa Semiarid. 2011;21-48.

4. Guimarães Júnior R, Gonçalves LC, Rodrigues JAS. Use of millet for silage production. Planaltina, DF: Embrapa Cerrados. 2009;30.

5. Erthal VJT, Ferreira PA, Pereira OG, et al. Physiological, nutritional and yield characteristics of forages fertigated with cattle wastewater. Revista Brasileira de Engenharia Agrícola e Ambiental. 2010;14(5):458-466.

6. Serafim RS. Production and chemical composition of Brachiaria brizantha cv Mandaru fertilized with swine wastewater. Tese (Doutorado em Produção Vegetal) - Universidade Estadual Paulista, Jaboticabal. $2010 ; 89$.

7. Alvares CA, Stape JL, Sentelhas PC, et al. Koppen's climate classification map for Brazil. Meteorologische Zeitschrift. 2013;22(6):711-728.

8. Brito AAF, Ferreira Neto M, Miranda NO, et al. Nutrient contents in red rice plants irrigated with domestic wastewater. Irriga. 2014;1(1):1-10.

9. Medeiros SS, Perez-Marin AM, Santos Júnior JA, et al. Hydric-nutritional potential of swine wastewater in the irrigation of cotton cultivated in semiarid conditions. Irriga. 2015;20(2):248-260.

10. Lira RB. Cultivation of sorghum using domestic sewage treated as a water source. 107f. Thesis (Doctorate in Soil and Water Management) - Federal Rural Semi-Arid University, Mossoró. 2016.

11. Rêgo LGS, Martins CM, Silva EF, et al. Pedogenesis and Soil Classification of an Experimental Farm in Mossoró, State of Rio Grande do Norte, Brazil. Revista Caatinga. 2016;29(4):1036-1042.

12. Silva DJ, Queiroz AC. Food analysis: chemical and biological methods. Viçosa, MG: UFV Publishing. 2002;235.

13. Ferreira DF. Sisvar: a computer statistical analysis system. Ciência e Agrotecnologia. 2011;35(6):1039-1042.

14. Quaresma JPS, Almeida RG, Abreu JG, et al. Production and bromatological composition of tifton 85 grass (Cynodon spp.). Maringá. 2011;33(2):145-150.

15. Detmann E, Souza MA, Valadares Filho SC. Methods for food analysis. National Institute of Science and Technology of Animal Science. Viscount of Rio Branco: Suprema. 2012;214.

16. Dias NS, Lira RB, Brito RF, et al. Melon yield in a hydroponic system with wastewater from desalination plant added in the nutrient solution. Revista Brasileira de Engenharia Agrícola e Ambiental. 2010;14(7):755-761.

17. Morais JM, Sobrinho JE, Santos WO, et al. Characterization of wind speed and direction in Mossoró/RN. Revista Brasileira de Geografia Física. 2014;7(4):746-754. 
18. National Research Council. Nutrient requirements of dairy cattle: 2001. Washington, DC: National Academies Press. 2001;381.

19. Rigo MM. Mineral composition and yield of fertigated forages with treated domestic sewage. (Master in Plant Production), Federal University of Espírito Santo, Alegre. 2011;56.
20. Simões KS, Peixoto MFSP, Almeida AT, et al. Treated wastewater from domestic sewage on soil microbial activity and growth of castor bean. Revista Brasileira de Engenharia Agrícola e Ambiental. 2013;17(5):518-523. 